\title{
Characteristics of Temperament of Preterm Toddlers and Their Relation to Early Language and Communication Development
}

\author{
YoonKyoung Lee ${ }^{\mathrm{a}}$, Jiyoung Lee ${ }^{\mathrm{b}}$ \\ ${ }^{a}$ Division of Speech Pathology and Audiology, Hallym University, Chuncheon, Korea \\ ${ }^{b}$ Department of Speech-Language Pathology and Audiology, Graduate School of Hallym University, Chuncheon, Korea
}

\author{
Correspondence: YoonKyoung Lee, PhD \\ Division of Speech Pathology and Audiology, \\ Hallym University, 1 Hallimdaehak-gil, Chunchon \\ 24252, Korea \\ Tel: +82-33-248-2219 \\ Fax: $+82-33-256-3420$ \\ E-mail: ylee@hallym.ac.kr
}

Received: July 5, 2017

Revised: August 22, 2017

Accepted: August 28, 2017

-This work was supported by the National Research Foundation of Korea Grant funded by the Korean Government (NRF-2014S1A5A2A01015713)

-Some results from the 2nd author's master's thesis was included in this study.
Objectives: This study aimed to examine the temperament characteristics of preterm toddlers and their relation to language and communication development. Methods: Twenty preterm and 20 full-term toddlers aged 18 to 24 months participated in this study. Temperament was measured with the Toddlers Temperament Scale (TTS) and language and communication were assessed using the Sequenced Language Scale for Infants (SELSI), Korean MacArthur-Bates Communication Development Inventory (K M-B CDI), and Communication and Symbolic Behavior Scale-Developmental Profile (CSBS-DP). Results: The preterm group had significantly more difficult temperament type, and showed significantly lower adaptability and avoidance temperament tendencies than the full-term group. The preterm group showed significantly lower performance in language and communication performance as measured by SESLI, KM-B CDI, and CSBS-DP. (3) Several significant correlation between temperament and language and communication was observed between CSBSDP and TTS scores in the preterm group. The consonant, gesture use, and emotion-eye gaze of CSBS-DP were significantly correlated to activity, approach-avoidance, and intensity of TTS. In the case of the full-term group, the activity score of TTS had a significant correlation with the expressive language age of SELSI and expressive vocabulary of K M-B CDI the communication and gesture use of CSBS-DP had a significant correlation with the adaptability of TTS and the gaze of CSBS-DP with the mood of TTS. Conclusion: We discussed the results focusing on the differences in temperament of preterm toddlers and how them affect on the language and communication development of the preterm toddlers.

Keywords: Premature, Toddler, Temperament, Language and communication development
미숙아 출생은 영유아 시기의 발달지연 위험 요인 중 하나로 알 려져왔다(Rossetti, 2001). 국외에서는 오래 전부터 미숙아 출생아 들의 발달적 위험성에 대해 관심을 갖고 추적 연구를 실시해 왔으 며, 이를 통해 미숙아 출생아들이 만삭아에 비해 높은 발달 지연이 나 발달 위험을 보고해 왔다(Koldewijn et al., 2008; Marlow, Roberts, \& Cooke, 1993; Marlow, Wolke, Bracewell, \& Samara, 2005; Roberts et al., 2008). 국내의 경우는 상대적으로 미숙아 출생아들 의 발달 문제에 관심이 미흡하였으나, 일부 연구자들이 미숙아 출 생아들이 12 개월 전후에는 발달 위험에 해당하는 경우가 $31.2 \%$ 로
만삭아에 비해 10 배 정도 높았으며(Ju, 2008), 24개월 미만의 경우 발달 위험이 만삭아의 3.5배(Bang, 2006)로 국외와 마찬가지로 높 은 발달위험을 보고하였다.

언어 및 의사소통 발달 측면에서도 유사한 연구 결과들이 보고 되어 왔다. Lee와 Lee (2013)는 국외에서 발표된 미숙아 출생아의 언어 및 의사소통 발달 관련 연구 30 편을 분석하였는데, 이중 25 편 의 연구에서 미숙아 집단이 만삭아 집단에 비해 언어 및 의사소통 발달이 유의하게 낮았다고 보고하였다. 또한 Lee와 Lee (2016a)는 12-30개월 사이의 국내 미숙아 86명과 만삭아 79명을 대상으로 언 
어발달검사를 직접 실시하여 비교하였는데, 언어발달지연(10백분 위수 미만)과 발달 위험(10에서 25백분위수 사이)에 해당하는 경 우가 만삭아 집단은 각각 $0 \%$ 와 $8 \%$ 였던 반면, 미숙아 집단은 각각 $37 \%$ 와 $24 \%$ 로 훨씬 높았다고 보고하였다.

이처럼 미숙아에게서 발달 지연이나 발달 위험이 높게 나타나는 이유에 대해 연구자들은 주로 조산이나 저체중 출생으로 인한 미 성숙한 신체 생리적 조건이나(Cusson, 2006; Marston, Peacock, Calvert, Greenough, \& Marlow, 2007), 출생 시부터 신생아집중치 료실 등에서의 입원 치료로 인해 갖게 되는 환경적 제약(Bang, Kang, Lee, \& Kwon, 2016; Ribeiro et al., 2011)을 중심으로 설명해 왔다. 즉 조산이나 저체중 출생으로 인한 생물학적 취약성이나 입원치료 로 인해 발달에 적절한 환경 탐색 기회 제한이 전반적 발달에 부정 적 영향을 미친다는 것이다.

이와 더불어 미숙아들의 기질적 차이도 발달에 영향을 미치는 주된 요인으로 고려되어 왔다(Coll, Halpern, Vohr, Seifer, \& Oh, 1992; Cosentino-Rocha, Klein, \& Linhares, 2014; Goldstein \& Bracey, 1988; Grunau, Whitfield, \& Petrie, 1994; Hughes, Shults, Mcgrath, \& Medoff-Cooper, 2002; Klein, Rocha, Martinez, Putnam, \& Linhares, 2013). 기질(temperament)이란 영유아가 출생하면서 부터 가지고 태어나는 성향으로 외부 자극에 대한 반응이나 반응 속도, 또는 기분과 관련된 행동 특성을 말한다(Thomas \& Chess, 1977). 기질은 영유아의 성격 발달의 모태가 될 뿐 아니라 사회성, 놀이, 인지, 언어 등 행동 전반의 발달에 중요한 영향을 미치며(Belsky, 1984; Jun, Choi, \& Choi, 2013), 유전적 속성이나 생물학적 메 커니즘과 매우 밀접한 관계를 갖기 때문에 미숙아와 같이 생물학 적으로 취약한 조건에 있는 경우에는 기질적으로도 취약한 상태 에 있을 수 있고, 궁극적으로는 발달에 부정적 영향을 미칠 수가 있 다(Pérez-Pereira, Fernández, Resches, \& Gómez-Taibo, 2016).

미숙아 기질 연구는 주로 기질 유형이나 기질을 구성하는 하위 요인별 특성을 중심으로 연구되어 왔다. 기질 유형은 일반적으로 순한 기질, 까다로운 기질, 느린 기질로 구분되는데, 대체로 순한 기 질의 영유아에 비해 까다로운 기질의 영유아가 적응이 어렵고, 기 분이나 행동 반응이 불안정하여 발달에 문제를 갖는 경우가 많다 (Jun et al., 2013; Kim \& Cho, 2007). 영아들의 기질 유형을 살펴본 Chess와 Thomas (1985)는 일반 영아의 경우 순한 기질이 $40 \%$, 까 다로운 영아 $10 \%$, 느린 영아 $15 \%$, 기타 분류가 어려운 경우가 $35 \%$ 로 대부분의 영아가 순한 기질을 갖고 있다고 보고하였다. 반면 미 숙아를 대상으로 한 연구에서는, Weiss, John-Seed와 Wilson (2004) 은 약 $80 \%$ 가 까다로운 기질을 가지고 있다고 보고한 반면, Ross (1987)나 Goldstein과 Bracey (1988)는 미숙아들이 기질의 하위 요
인에서는 유의한 차이가 있었으나, 기질유형에서는 차이를 보이지 않는다고 서로 다른 결과를 보고하였다.

기질 구성요인을 중심으로 한 연구들은 대체로 미숙아들이 만 삭아 집단과 기질에서 차이가 있었다고 보고하였다. 기질 구성요인 은 연구자들에 의해 다양하게 제시되는데(Buss \& Plomin, 1984; Rothbart \& Bates, 2006; Thomas \& Chess, 1977), 대체로 기분과 같 은 정서적 요인이나 활동성, 접근성, 적응성, 반응강도 등과 같은 행 동 반응 또는 통제 요인을 포함한다. 미숙아를 대상으로 한 연구들 은 미숙아들이 행동 반응이나 측면에서 행동이 규칙적이지 않고, 자극에 집중하는 정도가 낮으며(Goldstein \& Bracey, 1988; Hughes et al., 2002), 외부 자극에 대한 반응강도가 크고(Goldstein \& Bracey, 1988), 새로운 자극이 주어졌을 때 회피하는 경향이 높다(Hughes et al., 2002)는 기질적 특성을 보고하였다. 또한 정서적 측면에 서는 부정적인 정서를 더 많이 표현하고(Coll et al., 1992; Cosentino-Rocha et al., 2014; Klein et al., 2013), 달래기 어려운(Klein et al., 2013) 기질적 경향을 갖는다고 보고하였다. 이와 같은 기질적 특성 은 미숙아들이 새로운 환경에 적응하거나 양육자와의 상호작용을 방해하고, 궁극적으로 발달에 부정적 영향을 미칠 수 있다.

기질은 영유아의 언어 및 의사소통 발달과도 관계를 갖는다고 알려져 왔다. 주로 일반 영유아를 대상으로 한 연구들은 까다로운 기질의 영유아는 순하거나 느린 영유아에 비해 언어발달이 느리며 (Cho \& Hong, 2010), 적응력이 떨어지거나, 활동량이 많은 경우, 그 리고 긍정적 정서에 비해 부정적 정서 상태에 있을수록 언어발달 이 느린 경향이 있었다(Kim \& Shin, 2013; Lee, Park, Kim, Chang, \& Choi, 2008)고 보고하였다. 미숙아 집단을 대상으로 기질과 언어 발달의 관계를 종단적으로 살펴본 Pérez-Pereira 등(2016)도 기질 중 긍정적 정서의 부족과 접근-회피에서 낮은 접근성 등이 언어발 달에 부정적 영향을 미치는 것으로 보고한 바 있다.

영아의 기질적 특성과, 기질과 발달과의 관계를 이해하는 것은 영아에게 적절한 양육이나 교육을 제공하여 발달을 촉진하기 위한 환경을 만들어 주는 데에 매우 중요하다(Jun et al., 2013). Thomas 와 Chess (1977)는 영유아의 기질에 맞는 적절한 양육이나 환경이 제공되는 경우 발달에 바람직한 결과를 도출할 수 있으나, 반대로 영아의 기질에 적합하지 않은 부적절한 양육 또는 환경이 제공되는 경우 영아 발달은 악순환의 길로 진행될 수 있다고 하였다. 따라서 영아에게 적합한 양육이나 교육적 환경을 제공하기 위해서는 기질 과 발달적 관계를 이해하는 것이 중요하다. 특히 미숙아와 같이 발달 위험 상태에 있는 영아들에게는 그 중요성이 더 크다고 할 수 있다.

최근 우리나라는 출생률이 급감하고 있는 반면, 미숙아 출생률 은 증가하고 있다. 1990년대 이후부터 2000년까지 약 10년 동안 미 
YoonKyoung Lee, et al. • The Relation between Temperament and Language Development in Preterm Toddlers COMmuniCATION SCIENCES\& DISORDERS

숙아 출생 빈도가 약 3배 증가하였으며(Park, Song, \& Park, 2000), 2001년에 3.95\%였던 미숙아 출생률이 2012년에는 5.34\%, 2014년에 는 5,7\%로 매해 꾸준히 증가하고 있다(Korean Statistical Information Service, 2014). 이처럼 미숙아 출생률이 증가하고 있음에도 불 구하고, 미숙아의 발달이나 물론 발달에 영향을 미칠 수 있는 요인 에 대한 연구는 매우 부족하다. 본 연구는 이러한 맥락에서 기질적 요인을 중심으로 미숙아 언어 및 의사소통 발달에 미치는 영향을 살펴보는 것을 목적으로 미숙아 집단의 기질적 특성을 만삭아 집 단과 비교하고 각각의 집단에서 기질 요인과 언어 및 의사소통 발 달과의 관계를 살펴보았다.

\section{연구방법}

\section{연구대상}

본 연구는 $18-24$ 개월 사이의 미숙아 출생 영아 20 명, 미숙아 출 생 영아와 생활연령을 일치시킨 만삭 영아 20 명, 총 40 명의 영아를 대상으로 하였다. 18-24개월 영아를 대상으로 한 이유는 이 시기가 다른 시기에 비해 기질이 갖는 영향이 큰 시기이며(Chang-Song, Lee, Choi, \& Lee, 2007), 의사소통적 측면에서도 언어를 통한 의사 소통기로 전환하는 시기로(Lee \& Lee, 2016b) 기질이 언어와 의사 소통에 미치는 영향을 살펴보기에 적절하다고 판단하였다.

미숙아는 출생 시 몸무게가 $2,500 \mathrm{~g}$ 미만이고 재태기간 37주 미 만으로 출생한 영아로 정의하였다(Sansavini et al., 2010). 일반적으 로 24개월 미만의 미숙아를 대상으로 발달을 살펴볼 때에는 교정 연령(corrected age)을 적용하도록 권고되나, 기질적 특성을 살펴 본 연구에서는 대부분 교정연령이 아닌 생활연령을 적용하므로 (Cosentino-Rocha et al., 2014; Goldstein \& Bracey, 1988; Klein et al., 2013) 본 연구에서도 교정연령이 아닌 생활연령을 기준으로 대 상을 표집하였다. 비교집단인 만삭 영아는 양육자 보고에 의해 출 생 시 몸무게가 $2,500 \mathrm{~g}$ 이상이며, 재태기간이 37주 이상이 영아 중 에서 미숙아와 개별적으로 비교하여 생활연령이 \pm 1 개월에 해당 하는 영아를 표집하였다. 연구에 참여한 영아는 모두 양육자 보고 에 의해 임신 및 출산 중이나 출생 후 발달에 문제가 없었으며, 한 국판 베일리 영아발달검사(Bayley Scale of Infant Development-II, K-BSID-II; Cho \& Park, 2006)의 검사 결과가 정상 범위에 속하였 다. 미숙아와 만삭아 모두 발달에 영향을 미칠 수 있는 외재적 요인 을 배제하고자(Hoff \& Tian, 2005) 부모의 학력은 고졸 이상, 사회 경제적 수준은 중류층 이상으로 통제하였다.

본 연구 참가자 정보는 Table 1 과 같다. 두 집단은 생활연령에서 는 유의한 차이가 없었으나 재태기간, 출생 시 몸무게, K-BSID-II의
Table 1. Participations' information

\begin{tabular}{lccc}
\hline & Preterm (N=20) & Full-term (N=20) & $t$ \\
\hline Chronological age (mo) & $20.65(2.43)$ & $20.68(2.31)$ & -.045 \\
Gestational age (wk) & $28.85(2.75)$ & $39.32(0.88)$ & $-15.776^{* * *}$ \\
Birth weight (kg) & $1.30(0.46)$ & $3.28(0.34)$ & $-15.057^{* * *}$ \\
K-BSID II Mental & $92.7(17.40)$ & $120.37(11.49)$ & $-5.825^{* * *}$ \\
K-BSID II Motor & $86.85(23.07)$ & $114.05(13.86)$ & $-4.433^{* * *}$
\end{tabular}

Values are presented as mean (SD).

K-BSID-II = Bayley Scale of Infant Development-II (Cho \& Park, 2006). ${ }^{* *} p<.01,{ }^{* * *} p<.001$

결과에서 유의한 차이가 있었다.

\section{연구도구}

영아의 기질을 측정하기 위해 Baek (1996)이 번안한 Toddler Temperament Scale (TTS)을 사용하였다. TTS는 Fullard, McDevit와 Carey (1984)가 개발하고 Saslow (1993)가수정한 것으로 국내외 영 아 기질 연구에서 폭넓게 사용된 도구로 국내 영아에게도 적용 가 능한 척도로 평가되고 있다(Chang-Song et al., 2007). TTS는 1-3세 영아의 기질을 측정하는 도구로 기질을 활동성(activity), 접근-회피 (approach-withdrawal), 적응성(adaptability), 반응강도(intensity), 기분 $(\mathrm{mood})$ 의 5 가지 요인으로 측정하며, 총 51 개의 문항으로 구성 되어 있다. 각 요인별 정의와 점수의 의미는 다음과 같다. (1) '활동 성’은 영아의 신체움직임이나 활동 정도를 말하며, 점수가 클수록 신체움직임이나 활동이 많은 것을 의미한다. (2) '접근-회피'는 새로 운 자극을 접했을 때 회피하는 것을 말하며, 점수가 클수록 회피하 는 정도가 큰 것을 의미한다. (3) '적응성'은 새로운 상황에 적응하 는 능력을 말하며, 점수가 클수록 쉽게 적응하지 못하는 것을 의미 한다. (4) '반응강도'는 외부 자극에 대한 반응 표현 정도를 말하며, 점수가 클수록 반응을 격렬하게 표현하는 것을 의미한다. (5) '기분' 은 정서적 상태를 말하며, 점수가 클수록 부정적 기분 상태를 의미 한다.

영아들의 언어능력은 국내 영아들을 대상으로 표준화된 언어검 사인 영유아 언어발달검사(SELSI; Kim, Kim, Yoon, \& Kim, 2003) 와 한국판 맥아더-베이츠 의사소통 검사(K M-B CDI; Pae \& Kwak, 2011)를 사용하여 측정하였다. SELSI는 생후 4-35개월 영유아의 전 반적인 언어 및 의사소통 능력을 평가하기 위하여 고안된 검사로 수용언어와 표현언어로 구성되어 있으며, 화용, 의미, 음운, 문법 등 영유아의 언어발달에 대한 전반적인 정보를 제공해준다. K M-B CDI는 Fenson 등(2007)에 의해 개발된 M-B CDI를 Pae와 Kwak (2011)이 한국판으로 표준화한 검사도구로 영아용과 영유아용 두 가지 버전이 있는데 본 연구에서는 18-24개월 영유아를 대상으로 
하였으므로 영유아용을 사용하였다. SELSI와 K M-B CDI 모두 국 내 영아들을 대상으로 신뢰도와 타당도가 보고되었다.

의사소통 능력은 Communication and Symbolic Behavior Scales Developmental Profile (CSBS DP; Wetherby \& Prizant, 2002)를 사용하여 측정하였다. CSBS DP는 6 개월에서 24 개월의 영아의 의 사소통과 상징행동을 평가하기 위해 고안된 검사도구로 반구조화 된 절차를 통해 표집된 영아의 행동을 관찰하여 평가하는 행동평 가척도와 양육자에게 설문형태의 평가지를 작성하도록 하여 평가 하는 양육자평가척도로 구성된다. 본 연구에서는 검사자가 직접 영아의 행동을 유도하여 평가하는 행동평가척도를 사용하였다. CSBS DP는 국내 영아 대상으로 신뢰도 및 타당도가 보고되고 있 지는 않았으나 영아기 의사소통 발달 연구에 폭넓게 활용되고 있 다(Jeon, Lee, \& Lee, 2013; Lee \& Lee, 2014).

\section{자료수집 절차}

본 연구의 대상자 모집 및 모든 연구 절차는 연구자가 속한 대학 교의 생명윤리위원회의 승인을 받았다(HIRB-2014-24). 연구 참가 자는 육아관련 온라인 카페에 안내글을 게시하여 모집하였으며, 참여를 희망한 어머니들과 개별적으로 연락하여 검사 일정을 조율 한 후, 어머니와 조율한 날짜와 시간에 가정으로 방문하여 자료를 수집하였다. 자료 수집 전에 어머니에게 연구 목적과 절차 및 검사 내용 등을 설명한 후, 어머니가 연구 참여 및 절차를 이해하고 동의 한 경우 동의서에 서명을 받은 후 검사를 실시하였다.

먼저 어머니에게 기본 정보 기록지, TTS (Baek, 1996), SELSI (Kim et al., 2003) 및 K M-B CDI (Pae \& Kwak, 2011) 작성 방법을 안내하 였다. 세 검사 모두 어머니가 직접 읽고 응답하게 하였으며 이해에 어려움을 갖는 문항은 연구자가 설명해주었다. 검사가 완료된 후에 는 빠뜨린 문항은 없는지 검토하고 추가 질문하여 모든 문항에 빠 짐없이 답하게 하였다.

어머니가 TTS, SELSI, K M-B CDI를 작성한 이후 연구자가 영아 를 대상으로 CSBS DP를 실시하였다. 집에 영유아용 책상과 의자 가 있는 경우에는 의자에 앉게 하여 검사를 실시하였으며, 영유아 용 책상이나 의자가 없는 경우에는 집에 있는 낮은 테이블을 사용 하여 검사를 실시하였다. 어머니는 영아 옆쪽에 자리하도록 지시하 였으나, 혼자 착석이 어려운 일부 영아는 어머니의 무릎에 앉힌 자 세로 검사를 실시하였다. 검사자는 사전에 어머니에게 검사의 목적 과 실시 과정을 알려주었으며, 검사 중에 영아에게 단서를 제공하 거나 수행을 돕는 말과 몸짓을 하지 않도록 안내하였다. CSBS DP의 모든 절차는 추후 채점과 신뢰도 평가를 위하여 보호자의 동의를 얻어 캠코더(Samsung DCR-SX83)로 녹화하였다.

\section{자료 분석 및 측정}

기질 유형 및 하위 요인별 점수

기질은 기질 유형과 기질의 하위 요인별 점수를 측정하였다. 기질 유형은 Saslow (1993)의 기질 유형 분류를 기초로 하여 순한 기질, 까다로운 기질, 느린 기질의 세 가지로 분류하였다. 기질 유형을 나 누기 위해서 Lee 등(2008)이 제시한 TTS의 국내 영유아의 월령별 평균값에 근거하여 다섯 가지 하위 요인 중에서 획득한 점수의 합 은 각각 문항 수로 나누어 각 요인의 값을 구하였다. 요인의 평균값 이 +1 표준편차인 요인이 2 개 이상일 경우 까다로운 기질, -1 표준 편차인 요인이 2개 이상일 경우 느린 기질, 앞선 두 경우가 아닌 경 우 순한 기질로 분류하였다.

기질의 하위 요인별 점수는 Baek (1996)에서 제시한 채점 기준에 따라 채점하여 5 가지 요인별 점수를 측정하였다.

\section{언어 및 의사소통 평가}

SELSI는 수용언어와 표현언어 정답 문항을 산출하였으며, 측정 된 점수에 기초하여 수용언어발달연령, 표현언어발달연령, 통합언 어발달연령을 측정하였다. K M-B CDI는 유아용의 경우 표현어휘 수만 측정하도록 권고된 지침에 따라 표현어휘수만 측정하였다.

CSBS DP는 검사 매뉴얼에 제시된 채점 절차에 따라 채점하였으 며, 총점, 세 구성요인(composite) 점수(사회적, 발화적, 상징적 점 수), 일곱 개의 하위영역(cluster) 점수(정서 및 응시, 의사소통, 몸 짓, 말소리, 낱말, 이해, 상징놀이 점수)를 측정하였다.

\section{신뢰도}

신뢰도 측정을 위하여 언어병리학을 전공하며, 연구에서 사용된 검사와 척도 사용 훈련을 받은 석사과정생 1 명이 참여하였다.

신뢰도 측정에 앞서 각 검사와 척도의 채점 절차를 잘 숙지하고 있는지 확인을 하였으며, 2 명의 영유아 사례로 연습을 실시하였다. 신뢰도 평가자의 채점 결과가 연구자의 채점 결과와 $90 \%$ 이상의 일 치도에 도달하였을 때, 전체 자료의 $20 \%$ 를 무작위로 선정하여 독 립적으로 분석하게 하였다. 신뢰도는 연구자가 측정한 결과와 신뢰 도 평가자 간의 일치도로 측정하였다. 신뢰도 평가 결과 TTS, SELSI, K M-B CDI의 측정치는 $100 \%$ 의 일치도를 보였으며, CSBS-DP 는 $90.27 \%$ 를 보였다.

\section{통계분석}

통계 분석은 SPSS 통계 프로그램(Version 22)을 이용하여 실시 하였다. 미숙아 집단과 만삭 집단의 기질 유형과 요인별 특성, 언어 및 의사소통 발달에서 차이가 있는지 확인하기 위하여 각 검사 측 
YoonKyoung Lee, et al. • The Relation between Temperament and Language Development in Preterm Toddlers COMmuniCATION SCIENCES\& DISORDERS

정치에 대한 $\chi^{2}$ 검정 또는 두 독립표본 $t$-검정을 실시하였다. 또한 기 질 요인과 SELSI, K M-B CDI, CSBS-DP 측정치들과의 상관관계는 Pearson 상관분석 방법을 통해 확인하였다.

\section{연구결과}

\section{미숙아와 만삭아 집단의 기질 차이}

미숙아와 만삭아 집단의 기질 유형의 차이를 검정하기 위해 $\chi^{2}$ 검 정을 실시한 결과, 두 집단의 기질 유형 빈도 간에 유의한 차이 $\left(\chi^{2}=\right.$ $12.000, p<.01$ )가 있었다(Table 2). 미숙아 집단에서는 까다로운 기 질이 $60 \%$ (12명), 순한 기질 $40 \%$ (8명), 느린 기질은 0명이었던 반면, 만삭아 집단은 느린 기질과 순한 기질 모두 $40 \%$ (8명), 까다로운 기 질이 $20 \%$ (4명)로 나타났다.

미숙아와 만삭아 집단의 TTS로 측정한 기질 하위 요인의 차이를 검정하기 위해 $t$-검정을 실시한 결과, '접근-회피' $(t=2.208, p<.05)$ 와 ‘적응성' $(t=2.208, p<.05)$ 에서 유의한 차이가 있었다. 미숙아 집 단이 만삭아 집단에 비해 '접근-회피'와 '적응성'에서 유의하게 높 은 점수를 나타냈다(Table 3).

\section{미숙아와 만삭아 집단의 언어 및 의사소통 발달}

두 영아 집단의 언어 및 의사소통 검사 결과에서는 SELSI의 수용 언어발달연령, 표현언어발달연령, 통합언어발달연령, K M-B CDI 의 표현어휘 수, CSBS-DP의 총점과 세 구성요인의 점수, 그리고 일

Table 2. Frequency and percent of temperament types in the two toddler groups

\begin{tabular}{lccccc}
\hline & \multicolumn{3}{c}{ Temperament type } & \multirow{2}{*}{ Total } & $\chi^{2}$ \\
\cline { 2 - 4 } & Easy & Slow & Difficult & & \\
\hline Preterm & $8(40)$ & $0(0)$ & $12(60)$ & $20(100)$ & $12.000^{* *}$ \\
Full-term & $8(40)$ & $8(40)$ & $4(20)$ & $20(100)$ & \\
\hline
\end{tabular}

Values are presented as number of toddler $(\%)$. ${ }^{* *} p<.01$.

Table 3. Comparison of TTS sub-factors' scores between the two toddler groups

\begin{tabular}{lccc}
\hline TTS sub-factors & Preterm $(\mathrm{N}=20)$ & Full-term $(\mathrm{N}=20)$ & $t$ \\
\hline Activity & $25.25(3.35)$ & $24.10(2.84)$ & 1.169 \\
Approach-withdrawal & $24.70(3.40)$ & $22.15(3.88)$ & $2.208^{*}$ \\
Adaptability & $23.50(2.35)$ & $19.55(1.93)$ & $5.805^{* * *}$ \\
Intensity & $28.15(2.39)$ & $27.90(2.93)$ & .295 \\
Mood & $28.95(3.15)$ & $27.70(3.08)$ & 1.268 \\
\hline
\end{tabular}

Values are presented as mean (SD).

TTS=Toddlers Temperament Scale.

${ }^{*} p<.05,{ }^{* * * *} p<.001$.
곱 가지의 하위영역 점수 모두에서 유의한 차이를 보였다(Table 4). 즉, 미숙아 집단이 만삭아 집단에 비해 유의하게 낮은수행을 보였다.

\section{기질과 언어 및 의사소통 발달 간의 상관관계}

두 영아 집단의 기질, 언어, 의사소통 능력 간의 관계를 살펴보기 위하여 TTS, SELSI, K M-B CDI, CSBS-DP 점수 간의 Pearson 상 관분석을 실시한 결과, 미숙아 집단은 TTS의 '활동성'점수가 CSBS $\mathrm{DP}$ 의 '말소리'점수와 부적상관이 있었으며 $(r=-.507, p<.05), \mathrm{TTS}$ 의 '접근-회피' 와 CSBS DP의 '몸짓' ( $r=.468, p<.05)$, TTS의 '반응 강도'와 CSBS DP의 '정서 및 눈 응시' $(r=.451, p<.05)$ 점수간에 유 의한 정적상관이 나타났다. 그 외 SELSI나 KM-B CDI로 측정한 언 어점수간에는 유의한 상관이 없었다(Table 4).

만삭아 집단에서는 TTS의 '활동성'이 SELSI의 표현언어연령 $(r=$ $-.464, p<.05)$ 및 $\mathrm{K} \mathrm{M}-\mathrm{B} \mathrm{CDI}$ 의 표현어휘수 $(r=-.489, p<.05)$ 와 부 적상관이 있었으며, TTS의 '접근-회피'점수와 SELSI의 표현어휘연 령 간에 정적상관 $(r=.468, p<.05)$ 이 있었다. TTS의 '반응강도'가 CSBS-DP에서는 구성요인 중 '사회적 영역' $(r=-.552, p<.05)$ 과, 하 위요인 중 ‘의사소통' $(r=-.594, p<.05)$, '몸짓 사용' $(r=-.451, p<.05)$

Table 4. Comparison of SELSI, K M-B CDI, and CSBS-DP scores between the two toddler groups

\begin{tabular}{lccc}
\hline & Premature & Full-term & $t$ \\
\hline SELSI & & & \\
RLA & $20.20(4.299)$ & $24.55(3.316)$ & $-3.583^{* *}$ \\
ELA & $16.95(4.489)$ & $23.00(3.509)$ & $-4.748^{* * *}$ \\
CLA & $18.55(4.249)$ & $23.95(3.502)$ & $-4.386^{* * *}$ \\
K M-B CDI & & & \\
Expressive vocab. & $49.05(76.132)$ & $183.50(145.106)$ & $-3.669^{* * *}$ \\
CSBS-DP & & & \\
Total & $63.10(31.908)$ & $120.00(20.876)$ & $-6.674^{* * *}$ \\
Social communication & $32.50(10.102)$ & $47.60(6.244)$ & $-5.686^{* * *}$ \\
Emotion \& gaze & $14.40(3.136)$ & $17.85(.366)$ & $-4.887^{* * *}$ \\
Communication & $10.10(4.483)$ & $16.55(3.348)$ & $-5.156^{* * *}$ \\
Gesture use & $8.00(3.598)$ & $13.20(3.270)$ & $-4.783^{* * *}$ \\
Speech & $11.90(9.894)$ & $37.65(11.080)$ & $-7.752^{* * *}$ \\
Sounds & $8.05(5.925)$ & $20.90(4.388)$ & $-7.795^{* * *}$ \\
Words & $3.85(4.344)$ & $16.75(7.348)$ & $-6.759^{* * *}$ \\
Symbolic & $18.70(15.187)$ & $34.75(8.245)$ & $-4.154^{* * *}$ \\
Understanding & $9.75(10.156)$ & $19.65(5.102)$ & $-3.895^{* * *}$ \\
Object use & $8.95(5.907)$ & $15.10(5.025)$ & $-3.546^{* *}$ \\
\hline
\end{tabular}

Values are presented as mean (SD).

SELSI = Sequenced Language Scale for Infants (Kim, Kim, Yoon, \& Kim, 2003); $R L A=$ receptive language age; $E L A=$ expressive language age; $C L A=$ combined language age; $\mathrm{K} \mathrm{M}-\mathrm{B} \mathrm{CDI}=$ Korean MacArthur-Bates Communication Development Index (Pae \& Kwak, 2011); CSBS-DP=Communication and Symbolic Behavior ScaleDevelopmental Profile (Wetherby \& Prizant, 2002).

${ }^{* *} p<.01,{ }^{* * *} p<.001$ 
Table 5. Correlations among TTS, SELSI, K M-B CDI, and CSBS-DP scores in the two toddler groups

\begin{tabular}{|c|c|c|c|c|c|}
\hline & & & $\pi S$ & & \\
\hline & Activity & Approach-withdrawal & Adaptability & Intensity & Mood \\
\hline Preterm & & & & & \\
\hline SELSI & & & & & \\
\hline RLA & -.172 & .263 & -.07 & -.07 & .327 \\
\hline ELA & -.114 & .340 & .167 & .064 & .189 \\
\hline CLA & -.162 & .394 & .271 & -.009 & .254 \\
\hline K M-B CDI & & & & & \\
\hline Expressive Vocab. & -.114 & .087 & .192 & -.096 & -.076 \\
\hline CSBS-DP & & & & & \\
\hline Total score & -.341 & .344 & .218 & -.285 & .086 \\
\hline Social & -.243 & .416 & .266 & -.332 & .216 \\
\hline Emotion \& gaze & -.215 & .337 & .221 & $-.451^{*}$ & .306 \\
\hline Communication & -.303 & .326 & .22 & -.267 & .079 \\
\hline Gesture use & -.118 & $.468^{*}$ & .28 & -.208 & .241 \\
\hline Speech & -.407 & .294 & .143 & -.066 & .184 \\
\hline Sounds & $-.507^{*}$ & .181 & .017 & -.131 & .113 \\
\hline Words & -.236 & .424 & .301 & .028 & .265 \\
\hline Symbolic & -.29 & .254 & .187 & -.334 & -.083 \\
\hline Understanding & -.312 & .231 & .155 & -.285 & -.107 \\
\hline Object use & -.209 & .256 & .214 & -.368 & -.028 \\
\hline Full-term & & & & & \\
\hline SELSI & & & & & \\
\hline RLA & -.291 & .263 & -.115 & -.070 & .094 \\
\hline ELA & $-.464^{*}$ & $.452^{*}$ & -.132 & -.199 & .375 \\
\hline CLA & -.353 & .399 & -.089 & -.154 & .291 \\
\hline K M-B CDI & & & & & \\
\hline Expressive vocab. & $-.489^{*}$ & .225 & -.232 & -.322 & .189 \\
\hline CSBS-DP & & & & & \\
\hline Total score & -.236 & .382 & -.399 & -.138 & .147 \\
\hline Social & -.161 & .306 & $-.552^{*}$ & -.080 & -.204 \\
\hline Emotion \& gaze & .015 & -.094 & .048 & -.161 & $-.555^{*}$ \\
\hline Communication & -.205 & .390 & $-.594^{*}$ & -.165 & -.070 \\
\hline Gesture use & -.098 & .196 & $-.451^{*}$ & .035 & -.255 \\
\hline Speech & -.273 & .305 & -.202 & -.124 & .352 \\
\hline Sounds & -.261 & .115 & -.074 & -.176 & .290 \\
\hline Words & -.256 & .391 & -.260 & -.082 & .357 \\
\hline Symbolic & -.109 & .325 & -.321 & -.123 & .055 \\
\hline Understanding & -.208 & .250 & -.178 & -.209 & .134 \\
\hline Object use & .032 & .280 & -.021 & -.315 & -.046 \\
\hline
\end{tabular}

SELSI = Sequenced Language Scale for Infants (Kim, Kim, Yoon, \& Kim, 2003); RLA= receptive language age; ELA= expressive language age; $C L A=$ combined language age; $K$ M-B CDI = Korean MacArthur-Bates Communication (Pae \& Kwak, 2011).

${ }^{*} p<.05,{ }^{* * *} p<.001$.

점수와 부적상관을 보였으며, TTS의 기분이 CSBS-DP의 정서 및 눈응시와 부적상관 $(r=-.555, p<.05)$ 을 보였다(Table 5).

\section{논의 및 결론}

본 연구는 발달에 영향을 미치는 요인 중 하나인 기질을 중심으 로 미숙아 집단이 만삭아 집단과 어떠한 차이를 보이는지, 기질이 
YoonKyoung Lee, et al. • The Relation between Temperament and Language Development in Preterm Toddlers COMMUNICATION SCIINCES \& DIIORDERS

언어 및 의사소통과 어떠한 관계를 갖는지를 살펴보는 것을 목적 으로 하였다.

\section{미숙아 출생 영아의 기질 특성}

미숙아와 만삭 영아 집단의 기질 유형을 비교한 결과에서는 미 숙아 집단은 까다로운 기질 유형이 $60 \%$, 순한 기질 유형이 $40 \%$ 로 나타난 반면, 만삭 집단은 느린 기질과 순한 기질이 각각 $40 \%$, 까다 로운 기질이 $20 \%$ 로 나타나 미숙아 집단이 까다로운 기질이 유의하 게 많은 것으로 나타났다. 관련 선행연구를 보면, 미숙아에게서 유 의하게 까다로운 기질이 많았다고 보고한 경우(Medoff-Cooper, 1986; Weiss et al., 2004)도 있으나 기질 유형에서 유의한 차이가 없 었다(Goldstein \& Bracey, 1988; Ross, 1987)는 결과가 보고되기도 하였다. 본 연구에서는 미숙아 집단에서 까다로운 기질이 유의하게 많은 것으로 나타나 미숙아의 기질 유형이 일반 영아들과 차이가 있다는 전자와 같은 결과를 나타냈다. Pérez-Pereira 등(2016)은 생 물학적으로 취약한 조건에 있는 경우에는 기질적으로도 취약한 상 태에 있을 수 있다고 하였다. 미숙아들이 갖는 생물학적 취약성은 기질에도 영향을 미쳐 상대적으로 까다로운 기질 영아가 차지하는 비율이 높아졌을 수 있다. 영아기에 까다로운 기질로 분류된 영아 들은 순한 기질의 영아에 비해 적응이 어렵고, 기분이나 행동 반응 이 불안정하여 발달에 문제를 갖는 경우가 많다(Jun et al., 2013; $\mathrm{Kim} \& \mathrm{Cho}, 2007)$. 또한 까다로운 기질의 영아는 행동 제어가 어려 워 강압적인 양육이나 보육이 제공되는 경우가 많으며, 이로 인해 성격 형성은 물론 발달에도 부정적 영향을 미치는 악순환적 고리 를 갖기 쉽다(Chess \& Thomas, 1985). 따라서 미숙아들이 상대적 으로 까다로운 기질을 갖기 쉬운 점을 고려하여 생후 초기부터 기 질적 특성을 고려한 접근이 요구된다.

기질의 하위 요인 점수를 비교한 결과에서는 '접근-회피'와 '적응 성' 요인에서 미숙아 집단이 유의하게 높은 점수를 보였다. '접근-회 피' 점수가 높다는 것은 새로운 자극을 접했을 때 그 자극에 적극 적으로 다가가기 보다는 회피하는 경향이 높은 기질이라는 것을 의 미하며, '적응성'의 점수가 높다는 것은 새로운 상황에 처하거나 환 경이 바뀌었을 때 그 상황이나 환경에 쉽게 적응하지 못한다는 것 을 의미한다. 이러한 점수의 의미에 기반할 때, 미숙아 집단이 만삭 아 집단에 비해 새로운 자극, 상황, 환경을 회피하거나 거기에 쉽게 적응하지 못하는 기질적 특징을 가지고 있다고 해석할 수 있다. 기 질의 하위 요인을 기반으로 미숙아의 기질적 특성을 살펴본 연구 들은 대체로 미숙아들이 규칙성이나 적응성과 같이 자기통제와 관 련된 기질 요인에서의 차이를 일관되게 보고하였다. 즉, 미숙아들 이 새로운 상황에서 접근하기보다는 회피하는 경향이 높으며(Hug- hes et al., 2002), 행동통제나 외부 자극에 대한 반응 측면에서 행동 이 규칙적이지 않고, 자극에 집중하는 정도가 낮기 때문에 적응성 에서도 어려움이 있다고 보고하였다(Goldstein \& Bracey, 1988; Hughes et al., 2002). 접근보다는 회피적 기질과 적응능력이 낮은 것으로 나타난 본 연구의 결과도 이러한 선행 연구의 결과들과 일 관된 결과를 보여주는 것이라 할 수 있다. 반면, 선행연구에서는 정 서적 측면에서 부정적인 정서와 관련된 결과가 다수 보고된 바 있 으나(Coll et al., 1992; Cosentino-Rocha et al., 2014; Klein et al., 2013) 본 연구에서는 기분 요인에서 유의한 차이가 없는 것으로 나타났 다. 그러나 통계적으로 유의하지 않았을 뿐, 본 연구에서도 미숙아 집단의 기분 평균 점수가 만삭 집단에 비해 높아 부정적 정서가 더 높게 나타난 점은 관심을 가져볼만 하다.

\section{미숙아 출생 영아의 언어 및 의사소통 특성}

두 영아 집단의 언어 및 의사소통 발달 검사 결과에서는 SELSI의 수용언어발달연령, 표현언어발달연령, 통합언어발달연령, $\mathrm{K} \mathrm{M-B}$ $\mathrm{CDI}$ 의 표현어휘수, $\mathrm{CSBS}-\mathrm{DP}$ 의 총점과 세 구성요인의 점수, 그리 고 일곱 가지의 하위영역 점수 모두 유의한 차이가 있는 것으로 나 타났다. 즉, 미숙아 집단이 만삭아 집단에 비해 유의하게 낮은 수행 을 보였다. 미숙아의 언어 및 의사소통 발달이 만삭아들에 비해 느 리게 발달한다는 사실은 여러 연구에서 보고된 바 있으며(Lee \& Lee, 2013; Koldewijn et al., 2008; Stolt et al., 2014; Taylor, Klein, Minich, \& Hack, 2000), 본 연구자에 의해 수행된 미숙아의 언어 및 의사소통 발달을 만삭아와 비교한 두 편의 연구에서도 동일한 결과가 보고된 바 있다(Lee \& Lee, 2014, 2016a).

Lee와 Lee (2014)는 15-33개월 사이의 미숙아 출생 영유아를 대 상으로 CSBS DP를 통해 측정된 사회적 의사소통 발달을 생활연 령을 일치시킨 만삭 영유아와 비교하였는데, 미숙아 집단이 만삭 영유아에 비해 CSBS DP의 총점 및 세 가지 구성요인 및 7가지 하 위 영역 모두에서 유의하게 낮아 18-24개월 영아만을 대상으로 한 본 연구와 같은 결과를 보고하였다. 또한 $12-30$ 개월 사이의 미숙아 86 명을 대상으로 SELSI와 K M-B CDI를 통해 언어적 특성을 살펴 본 Lee와 Lee (2016a) 연구에서도 미숙아 집단이 SELSI의 통합언어 연령, 수용언어연령, 표현언어연령과 $\mathrm{K} \mathrm{M-B} \mathrm{CDI의} \mathrm{표현어휘} \mathrm{수에}$ 서 유의하게 낮은 수행을 보고하였다. Lee와 Lee $(2014,2016 a)$ 는 본 연구와 동일한 연구 프로젝트를 통해 보고된 결과이기는 하나 12 개월에서 36 개월의 영아 집단을 대상으로 하여 본 연구보다 폭넓 은 연령대를 대상으로 연구되었고, 연구에 포함된 대상도 대부분 본 연구와 일치하지 않는다. 그럼에도 불구하고 일관되게 언어와 의 사소통 발달에서 유의한 차이를 보고하는 것은 미숙아의 언어 및 
의사소통 발달에 느리거나 발달 지연의 위험이 크다는 사실을 확 인해주는 것이라 할수 있다.

\section{미숙아 출생 영아의 기질과 언어 및 의사소통 발달과의 관계}

TTS, SELSI, K M-B CDI, CSBS-DP 점수 간의 Pearson 상관분석 을 통해 두 영아 집단의 기질, 언어, 의사소통 능력 간의 관계를 살 펴본 결과에서는, 미숙아 집단은 CSBS-DP의 일부 점수와만 기질 과 유의한 상관을 보인 반면, 만삭아 집단에서는 기질 요인이 CS$\mathrm{BS}-\mathrm{DP}$ 의 결과는 물론 SELSI와 K M-BDI로 측정한 언어점수와도 유의한 상관을 나타내 기질과 언어 및 의사소통 요인들 간의 유의 한 관계를 더 많이 보이는 것으로 나타났다. 18 개월과 24 개월 2 회에 걸쳐 영아의 기질과 언어발달 간의 관계를 종단적으로 살펴 본 Chang-Song 등(2007)은 18개월보다 24개월 때 기질 요인들이 언 어발달과 더 많은 상관을 나타냈다고 보고하였다. 본 연구에서 두 집단의 생활연령은 각각 20.65 개월과 20.68 개월로 거의 같았으나, 언어연령의 경우 SELSI 통합언어연령을 기준으로 미숙아 집단은 18 개월이나 만삭아 집단은 23.95 개월로 거의 24 개월에 해당하였 다. Chang-Song 등(2007)에 기초할 때 만삭 집단이 미숙아 집단에 비해 더 많은 언어 및 의사소통 점수와 기질 요인간에 유의한 상관 을 보인 것은 18 개월보다 24 개월 경에 기질과 언어 및 의사소통 요 인이 더 밀접하게 관련될 수 있다고 해석해 볼 수 있다. Lee와 Lee (2016b)는 한국 영유아의 의도적 의사소통행동 발달 연구를 통해 18 개월은 아직 의사소통을 목적으로 비언어적 수단을 활발하게 사용하며, 24 개월 경에 언어가 주된 의사소통 수단으로 대체되는 것으로 보고한 바 있다. 본 연구에서 언어발달연령이 평균 18 개월 이었던 미숙아 집단은 주로 CSBS-DP와만 유의한 상관을 보인 반 면, 언어발달연령이 평균 24 개월에 해당한 만삭아 집단은 CSBS$\mathrm{DP}$ 의 결과는 물론 SELSI와 KM-BDI로 측정한 언어점수와도 유의 한 상관을 보였다. 이는 미숙아 집단은 비언어적 의사소통을 주로 사용하고 있기 때문에 SELSI나 K M-B CDI와 같은 언어검사 결과 가 발달 경향을 민감하게 반영하지 못한 반면, 24 개월인 만삭아 집 단은 이미 언어가 주된 의사소통 수단으로 자리 잡는 시기이기 때 문에 발달 경향을 좀 더 민감하게 반영하였기 때문으로 해석해 볼 수 있겠다.

기질과 언어 의사소통 세부 요인 간의 관계를 보면, 미숙아 집단은 TTS의 ‘활동성'과 CSBS DP의 '말소리’, TTS의 ‘반응강도'와 CSBS $\mathrm{DP}$ 의 ‘정서 및 눈 응시' 간에 부적상관을 TTS의 ‘접근-회피'와 CSBS $\mathrm{DP}$ 의 '몸짓 사용'에서는 정적상관을 나타냈다. 앞에서도 이미 서술 하였듯이, TTS의 ‘활동성'과 ‘반응강도'는 점수가 클수록 활동 정 도나 외부 자극에 대한 반응 강도가 큰 것을 의미하므로, '활동성'
과 ‘말소리’ 간에, ‘반응강도'와 ‘정서 및 눈 응시’ 간에 부적상관을 나타낸 것은 신체 움직임이나 활동량이 많을수록 말소리 발달이 느리며, 외부 자극에 대한 반응 강도가 클수록 상대방과 정서나 시 선을 공유하는 행동을 잘 하지 않는다는 것으로 해석할 수 있다. 활 동량이 많은 영아일수록 양육자나상호작용 상대방의 언어적 자극 에 주의를 두지 않고, 반응 강도가 클수록 행동 통제가 어렵고 새로 운 상황에 적응하는 데 어려움을 가질 수 있다(Cho \& Hong, 2010). 본 연구의 결과는 미숙아 집단이 상대적으로 활동량이 많아 이것이 양육자와의 상호작용을 방해하고 궁극적으로 말소리 습득에도 영 향을 미칠 수 있음을 보여 준다.

반면, '접근-회피'는 '몸짓 사용'과는 정적상관을 보였는데, '접근회피'는 점수가 클수록 회피 정도가 높은 것을 의미하므로 영아가 회피 성향을 보일수록 몸짓 사용이 많아진다는 것으로 해석할 수 있을 것이다. CSBS-DP에서 몸짓 사용은 영유아가 사용한 관습적 몸짓의 유형 수와 각각의 유도 활동 중에 원거리 몸짓이 나타났는 지 여부를 통해 측정한다. 원거리 몸짓은 검사자와 적당한 거리를 유지하는 상황에서 사용되기 쉬우므로 접근 보다는 회피적 성향 을 보인 영아에게서 더 많이 관찰된 것은 아닌가 추측해 볼 수 있다. 활동량이 많거나 자극에 대한 반응의 정도가 격렬할수록 언어발 달은 느린 경향이 있다는 결과는 선행 연구에서도 일관되게 보고 되어 왔다(Chang-Song et al., 2007; Cho \& Hong, 2010; Kim \& Shin, 2013).

미숙아 집단에서는 ‘활동성’이나 ‘반응강도', ‘접근-회피’ 요인이 각각 CSBS-DP의 ‘말소리', '정서 및 눈응시', ‘몸짓 사용'과 정적관계 를 나타낸 반면, 만삭아의 경우는 기질의 '적응성'이 CSBS-DP 구 성요인 중 사회적 영역과, 하위요인 중 ‘의사소통', '몸짓 사용'과 부 적상관을 보였으며, '기분’이 CSBS-DP의 '정서 및 눈 응시'와 부적 상관을 보였다. '적응성'은 점수가 클수록 쉽게 적응하지 못하는 것 을 의미하며, 기분은 점수가 높을수록 부정적 정서 상태에 있음을 의미한다. 따라서 각 요인간에 나타난 정적상관은 적응성이 좋을 수록 의사소통 행동이나 몸짓 사용이 많으며, 긍정적 정서 상태를 보일수록 다른 사람과의 정서 및 사회적 상호성이 좋음을 의미한 다. 대체로 미숙아들은 활동성이나 반응강도가 큰 것이 의사소통 행동과 부정적 관계를 갖는 것으로 나타났으나, 만삭아 집단은 적 응력이 좋고 기분 상태가 좋을수록 의사소통행동이 활발한 것으 로차이를 보였다.

이 외에도 만삭아 집단에서는 TTS의 '활동성'이 SELSI의 표현언 어연령 및 K M-B CDI의 표현어휘수와 부적상관이 있었으며, TTS 의 '접근-회피'와 SELSI의 표현어휘 간에 정적상관이 있었다. 앞에 서도 서술하였듯이 ‘활동성' 점수가 높을수록 활동량이 많으며, 
YoonKyoung Lee, et al. • The Relation between Temperament and Language Development in Preterm Toddlers COMmuniCATION SCIENCES\& DISORDERS

‘접근-회피' 점수가 높을수록 회피적 성향이 큰 것을 의미하므로 활동 수준이 높고 많고 회피적 성향이 클수록 표현언어능력은 좋 지 않은 것으로 해석할 수 있다. 이러한 결과는 미숙아 집단에서 CSBS-DP의 말소리 및 몸짓 사용과 활동성 및 접근-회피 요인 간에 서 확인된 결과와 유사하다. 두 영아 집단에서 나타난 결과를 토대 로 볼 때, 활동성과 회피적 성향이 클수록 초기 의사소통과 언어발 달에 부정적 영향을 미치는 것으로 종합해 볼 수 있겠다(Chang-

Song et al., 2007; Cho \& Hong, 2010; Kim \& Shin, 2013).

본 연구 결과를 종합하면, 미숙아 집단은 만삭아 집단에 비해 기 질적으로 회피적이며, 부적응적 성향을 높게 나타냈으며, 상대적으 로 까다로운 기질로 분류되는 경우가 유의하게 많은 것으로 나타 났다. 또한 언어 및 의사소통 전반에 걸쳐 만삭아 집단에 비해 발달 이 유의하게 느렸으며, 언어 및 의사소통 발달이 활동성이나 반응 강도 같은 기질적 요인과 유의하게 관련됨을 보여주었다. 이러한 결 과는 미숙아 출생이 영아의 기질적 특성이 의사소통 및 언어 발달 과 밀접하게 관련될 수 있으므로 초기 의사소통 및 언어 발달에 대 한 조기 중재를 제공할 때 이러한 기질적 요인에 대해 고려해야 함 을 시사한다.

장애인 등에 대한 특수교육법이나 장애아동복지지원법에서는 3 세 미만의 어린 영아들의 경우는 발달장애가 확인되지 않더라도 장애위험요인이 높은 집단은 조기중재 서비스 대상으로 포함한다. 미숙아 집단은 만삭 영아 집단에 비해 발달지연의 위험이 큰 집단 으로, 발달지체 또는 장애가 확인되지 않더라도 예방적 차원에서 의 조기 개입이 강조되어야 한다. 특히 언어 및 의사소통 발달은 인 지발달은 물론 사회-정서 발달에도 영향을 미치므로(Lee, 2011) 조 기개입을 결정하기 위한 조기선별이 매우 중요하다. 적절한 개입을 위해서는 각 영아의 현행 수행만이 아니라 발달에 영향을 미칠 수 있는 요인에 대한 고려가 필요하다. 본 연구는 발달 위험 집단인 미 숙아 출생 영아 집단에서 기질과 언어 및 의사소통 발달이 기질과 어떠한 관계를 갖는지를 살펴보았다는 점에서 의의를 갖는다. 본 연구는 각 집단이 20 명으로 사례수가 많지 않았으며, 때문에 출생 시 몸무게나 재태기간과 등과 같이 기질이나 언어 또는 의사소통 발달에 영향을 줄 수 있는 요인들에 대해 충분히 고려하지 못하였 다. 이러한 부분은 추후 연구를 통해 확인되어야할 것이다.

\section{REFERENCES}

Baek, K. S. (1996). A study on children's adjustment to full-time daycare center

(Doctoral dissertation). Sookmyung Women's University, Seoul, Korea.

Bang, K. S. (2006). A comparisons of characteristics of infants born prema- turely according to results of Denver II screening test. Child Health and Nurse Research, 12, 398-404.

Bang, K. S., Kang, H. J., Lee, B., \& Kwon, M. K. (2016). Prospective study on factors related to development in premature infants at six-months. Child Health and Nurse Research, 22, 199-206.

Belsky, J. (1984). The determinants of parenting: a process model. Child Development, 55, 83-96.

Buss, A. H., \& Plomin, R. (1984). Theory and measurement of EAS. In A. H. Buss \& R. Polmin (Eds.), Temperament: early developing personality traits (pp. 98-130). London: Psychology Press.

Chang-Song, Y. K., Lee, K. Y., Choi, Y. L., \& Lee, S. (2007). The effect of infants' temperament on early vocabulary acquisition at 18 and 24 months. The Korean Journal of the Human Development, 14, 23-42.

Chess, S., \& Thomas, A. (1985). Temperamental differences: a critical concept in child health care. Pediatric Nursing, 11, 167-171.

Cho, B. H., \& Park, H. W. (2006). Korean Bayley Scales of Infant Development II (K-BSID-II). Seoul: Mindpress.

Cho, Y. N., \& Hong, J. E. (2010). The effect of infants' temperament and the maternal parenting behavior on infants' receptive language and expressive language development. Korea Journal of Child Care and Education, 64, 99117.

Coll, C. T. G., Halpern, L. F., Vohr, B. R., Seifer, R., \& Oh, W. (1992). Stability and correlates of change of early temperament in preterm and full-term infants. Infant Behavior and Development, 15, 137-153.

Cosentino-Rocha, L., Klein, V. C., \& Linhares, M. B. M. (2014). Effects of preterm birth and gender on temperament and behavior in children. Infant Behavior and Development, 37, 446-456.

Cusson, R. M. (2006). Factors influencing language development in preterm infants. Journal of Obstetric, Gynecologic, and Neonatal Nursing, 32, 402409.

Fenson, L., Marchman, V. A., Thal, D. J., Dale, P. S., Reznick, J. S., \& Bates, E. (2007). MacArthur-Bates Communicative Development Inventories: user's guide and technical manual (2nd ed.). Baltimore, MD: Brookes.

Fullard, W., McDevitt, S. C., \& Carey, W. B. (1984). Assessing temperament in one-to three-year-old children. Journal of Pediatric Psychology, 9, 205217.

Goldstein, D. J., \& Bracey, R. J. (1988). Temperament characteristics of toddlers born prematurely. Child: Care, Health and Development, 14, 105-109.

Grunau, R. V., Whitfield, M. F., \& Petrie, J. H. (1994). Pain sensitivity and temperament in extremely low-birth-weight premature toddlers and pre- 
term and full-term controls. Pain, 58, 341-346.

Hoff, E., \& Tian, C. (2005). Socioeconomic status and cultural influences on language. Journal of Communication Disorders, 38, 271-278.

Hughes, M. B., Shults, J., Mcgrath, J., \& Medoff-Cooper, B. (2002). Temperament characteristics of premature infants in the first year of life. Journal of Developmental \& Behavioral Pediatrics, 23, 430-435.

Jeon, J., Lee, H., \& Lee, Y. (2013). Comparison of language and social communication abilities of toddlers who are at risk of autism spectrum disorders and developmental language delay. Communication Sciences \& Disorders, 18, 349-359.

Ju, H. O. (2008). Growth and development in infants and children born prematurely who were registered at the public health center in G city. Journal of Korean Academy Child Health Nursing, 14, 44-52.

Jun, H. J., Choi, Y. K., \& Choi, H. J. (2013). Relationship among infants' temperament, mothers' child rearing attitudes and the social development of infants: mediation effects of communication. Early Childhood Education Research \& Review, 17, 365-384.

Kim, N. S., \& Cho, H. J. (2007). The features of toddlers' temperaments and the influence of toddlers' temperaments on their play behavior. Early Childhood Education Research \& Review, 11, 237-256.

Kim, Y. S., \& Shin, A. S. (2013). Abilities of infants' receptive language and expressive language according to infants' temperament and maternal parenting behavior. Korean Journal of Children's Media, 12, 157-176.

Kim, Y. T., Kim, K. H., Yoon, H. R., \& Kim, H. S. (2003). Sequenced Language Scale for Infants (SELSI). Seoul: Special Education Publishing.

Klein, V. C., Rocha, L. C., Martinez, F. E., Putnam, S. P., \& Linhares, M. B. M. (2013). Temperament and behavior problems in toddlers born preterm and very low birth weight. The Spanish Journal of Psychology, 16, E18.

Koldewijn, K., Wolf, M. J., van Wassenaer, A., Meijssen, D., van Sonderen, L., van Baar, A., ... \& Kok, J. (2009). The Infant Behavioral Assessment and Intervention Program for very low birth weight infants at 6 months corrected age. The Journal of Pediatrics, 154, 33-38.

Korean Statistical Information Service. (2014). Birth rate of preterm baby in 2014. http://kosis.kr

Lee, H. J., \& Lee Y. (2013). Literature review of premature child's communicative and language. The Korean Journal of Early Childhood Special Education, $13,327-346$.

Lee, H. J., \& Lee Y. (2014). Characteristics of social communication behavior in premature toddlers. The Korean Journal of Early Childhood Special Education, 14, 105-120.
Lee, H. M., Park, H. W., Kim, M. K., Chang, Y. K., \& Choi, Y. L. (2008). The stability of temperament during infancy: a short-term longitudinal study. Family and Environment Research, 46, 47-58.

Lee, Y. (2011). The relationships among language, communicative abilities and motor, cognitive, and socio-emotional development in toddlers with language delays. Korean Journal of Communication Disorders, 16. 1-12.

Lee, Y., \& Lee, H. (2016a). Prevalence of developmental language delay among toddlers born as preterm. Communication Sciences \& Disorders, 21, 60-68.

Lee, Y., \& Lee, H. (2016b). Development of intentional communicative behavior in Korean toddlers 12 to 30 months. Communication Sciences \& Disorders, 21, 553-566.

Marlow, N., Roberts, L., \& Cooke, R. (1993). Outcome at 8 years for children with birth weights of $1250 \mathrm{~g}$ or less. Archives of Disease in Childhood, 68, 286-290.

Marlow, N., Wolke, D., Bracewell, M. A., \& Samara, M. (2005). Neurologic and developmental disability at six years of age after extremely preterm birth. New England Journal of Medicine, 352, 9-19.

Marston, L., Peacock, J. L., Calvert S. A., Greenough, A., \& Marlow, N. (2007). Factors affecting vocabulary acquisition at age 2 in children born between 23 and 28 weeks' gestation. Developmental Medicine \& Child Neurology Volume, 49, 591-596.

Medoff-Cooper, B. (1986). Temperament in very low birth weight infants. Nursing Research, 35, 139-143.

Pae, S. Y., \& Kwak, K. J. (2011). Korean MacArthur-Bates communicative development inventories (K M-B CDI) user's guide and technical manual. Seoul: Mind Press.

Park, S. K., Song, C. H., \& Park, J. (2000). Actual condition of preterm baby management and policy making. Seoul: Jibmundang.

Pérez-Pereira, M., Fernández, P., Resches, M., \& Gómez-Taibo, M. L. (2016). Does temperament influence language development? Evidence from preterm and full-term children. Infant Behavior and Development, 42, 11-21.

Ribeiro, L. A., Zachrisson, H. D., Schjolberg, S., Aase, H., Rohrer-Baumgartner, N., \& Magnus, P. (2011). Attention problems and language development in preterm low-birth-weight children: cross-lagged relations from 18 to 36 months. BMC Pediatrics, 11, 59.

Roberts, G., Howard, K., Spittle, A. J., Brown, N. C., Anderson, P. J., \& Doyle, L. W. (2008). Rates of early intervention services in very preterm children with developmental disabilities at age 2 years. Journal of Paediatrics and Child Health, 44, 276-280.

Ross, G. (1987). Temperament of preterm infants: its relationship to perinatal 
YoonKyoung Lee, et al. • The Relation between Temperament and Language Development in Preterm Toddlers COMmuniCATION SCIENCES\& DISORDERS

factors and one-year outcome. Journal of Developmental \& Behavioral Pediatrics, 8, 106-110.

Rossetti, L. M. (2001). Communication intervention: birth to three. New York: Singular, Thomson Learning.

Rothbart, M. K., \& Bates, J. E. (2006). Temperament. In N. Eisenberg et al. (Eds.), Handbook of child psychology (pp. 99-166). Hoboken, NJ: John Wiley \& Sons.

Sansavini, A., Guarini, A., Justice, L. M., Savini, S., Broccoli, S., Alessandroni, R., \& Faldella, G. (2010). Does preterm birth increase a child's risk for language impairment? Early Human Development, 86, 765-772.

Saslow, E. R. (1993). Temperament and day care: an examination of differences in expression across settings (Doctorial dissertation). Temple University, Philadelphia, PA.

Stolt, S., Mäkilä, A. M., Matomäki, J., Lehtonen, L., Lapinleimu, H., \& Haata- ja, L. (2014). The development and predictive value of gestures in verylow-birth-weight children: a longitudinal study. International Journal of Speech-Language Pathology, 16, 121-131.

Taylor, H. G., Klein, N., Minich, N. M., \& Hack, M. (2000). Middle-schoolage outcomes in children with very low birthweight. Child Development, $71,1495-1511$.

Thomas, A., \& Chess, S. (1977). Temperament and development. New York: Brunner/Mazel.

Weiss, S. J., Jonn-Seed, M. S., \& Wilson, P. (2004). The temperament of preterm, low birth weight infants and its potential biological substrates. Research in Nursing \& Health, 27, 392-402.

Wetherby, A. M., \& Prizant, B. M. (2002). Communication and symbolic behavior scales developmental profile (manual). Baltimore, MD: The Brookes Publishing Co. 


\section{국문초록}

\section{미숙아 출생 영아의 기질 특성과 언어 및 의사소통 발달과의 관계}

이윤경 · 이지영

한림대학교 언어청각학부, 한림대학교 대학원 언어병리청각학과

배경 및 목적: 기질은 영아의 언어 및 의사소통 발달에 영향을 미치는 것으로 알려져 있다. 본 연구는 미숙아 출생 영아의 기질 특성을 살펴보고, 이러한 기질이 영아의 언어 및 의사소통 발달과 어떠한 관계를 갖는지 확인하고자 하였다. 방법: 연구 대상은 18-24개월 사이 의 미숙아 출생 영아 20 명과 생활연령을 일치시킨 만삭 영아 20 명으로, 총 40 명이였다. 기질은 Toddler Temperament Scale (TTS), 언어 는 Sequenced Language Scale for Infants (SELSI)와 Korea MacArthur-Bates Communication Development Inventory (K M-B CDI), 의사소통은 Communication and Symbolic Behavior Scale (CSBS-DP)을 사용하여 측정하였다. 측정된 결과는 두 독립표본 $t$-검정과 Pearson 상관분석으로 통계처리 하였다. 결과: 미숙아 집단은 만삭 집단에 비해 유의하게 까다로운 기질이 많았으며, 유의하게 낮은 적 응성과 회피적 기질을 보이는 것으로 나타났다. 미숙아 집단은 만삭 집단에 비해 SESLI, K M-B CDI, CSBS-DP로 측정한 언어와 의사소 통의 모든 측정치에서 유의하게 낮은 수행을 보였다. 미숙아 집단은 CSBS-DP의 말소리 산출과 활동성, 몸짓사용과 TTS의 접근-회피, 정서 및 눈응시, 반응강도와 각각 유의한 상관이 있었으며, 언어 측정치와는 기질요인 간의 유의한 상관은 없었다. 만삭 집단의 경우 SELSI의 표현언어연령 및 KM-CDI의 표현어휘수가 TTS 활동성 간에 유의한 상관이 있었으며, CSBS-DP의 의사소통, 몸짓 사용, 정서눈응시가 각각 TTS의 적응성과 기분과 유의한 상관이 있었다. 논의 및 결론: 미숙아 집단의 기질적 차이와 기질이 언어 및 의사소통 발 달에 미칠 수 있는 영향을 중심으로 논의하였다.

핵심어: 미숙아, 영아, 기질, 언어발달, 의사소통발달

- 이 논문은 2014년 정부(교육부)의 재원으로 한국연구재단의 지원을 받아 수행되었음(NRF-2014S1A5A2A01015713).

- 이 논문에는 제2저자 석사학위 논문의 결과가 일부 포함되었음.

\section{참고문헌}

국가통계청(2014). 2014 미숙아 출생률.http://kosis.kr

김난실, 조혜진(2007). 영아의 기질적 특성과 기질에 따른 놀이행동 분석. 유아교육학논집, 11, 237-256.

김영실, 신애선(2013). 영아의 기질 및 어머니의 양육행동에 따른 영아의 이해언어 및 표현언어 능력. 어린이미디어연구, 12, 157-176.

김영태, 김경희, 윤혜련, 김화수(2003). 영유아언어발달검사(SELSI). 서울: 도서출판 특수교육.

박상기, 송창훈, 박종(2000). 조산아 관리 현황 및 정책 수립 방안. 서울: 집문당.

방경숙(2006). 추후 덴버발달스크리닝 결과에 따른 미숙아의 특성 비교. 한국아동간호학회지, 12, 398-404.

방경숙, 강현주, 이부현, 권미경(2016). 미숙아로 출생한 영아의 6개월 발달 관련 요인에 대한 전향적 연구. 한국아동간호학회지, 22, 199-206.

배소영, 곽금주(2011). 맥아더-베이츠 의사소통발달 평가(K M-B CDI). 서울: 마인드프레스.

백경숙(1996). 영유아의 종일제 보육시설 적응에 영향을 미치는 관련 변인 연구. 숙명여자대학교 대학원 박사학위논문.

이윤경(2011). 언어발달지체 영유아의 언어 및 의사소통 능력과 인지, 운동 및 사회성 발달과의 관계. 언어청각장애연구, 16, 1-12.

이윤경, 이효주(2016a). 미숙아 출생 영유아의 언어발달지체 출현율. 언어청각장애연구, 21, 60-68.

이윤경, 이효주(2016b). 12-30개월 영유아의 의도적 의사소통 행동 발달. 언어청각장애연구, 21, 553-566.

이형민, 박혜원, 김말경, 장유경, 최유리(2008). 유아 기질의 안정성-단기종단분석. 대한가정학회지, 46, 47-58.

이효주, 이윤경(2013). 미숙아 출생 영유아의 언어 및 의사소통 발달 연구 동향. 유아특수교육연구, 13, 327-346.

이효주, 이윤경(2014). 미숙아출생 영유아의 사회적 의사소통 행동 특성. 유아특수교육연구, 14, 105-120. 
YoonKyoung Lee, et al. • The Relation between Temperament and Language Development in Preterm Toddlers

장유경, 이근영, 최유리, 이순목(2007). 18-24개월 영아의 기질과 어휘습득: 단기 종단적 연구. 인간발달연구, 14, 23-42.

전진아, 이효주, 이윤경(2013). 자폐범주성장애 의심 영유아와 언어발달지체 영유아의 언어및 사회적 의사소통 능력 비교. 언어청각장애연구, 18 ,

349-359

전홍주, 최유경, 최항준(2013). 영아의 기질과 어머니의 양육태도 및 영아의 사회성 발달 간의 관계: 의사소통의 매개효과. 유아교육학논집, $17,365-$

384 .

조복희, 박혜원(2006). 한국-베일리 영유아발달검사(K-BSID-II). 서울: 마인드프레스.

조유나, 홍지은(2010). 영아의 수용언어 및 표현언어 발달에 대한 영아의 기질과 어머니 양육행동의 영향. 한국영유아보육학, 64, 99-117.

주현옥(2008). G시 보건소에 등록된 미숙아의 영유아기 성장과 발달 상태. 한국아동간호학회지, 14, 44-52. 